Article

\title{
Gender as a Determining Factor in the Family History and Development of the McGee Family
}

\author{
Thomas Daniel Knight \\ Department of History, The University of Texas-Rio Grande Valley, 1201 West University Drive, Edinburg, \\ TX 78539, USA; thomas.knight@utrgv.edu
}

Received: 31 May 2017; Accepted: 7 July 2017; Published: 24 July 2017

\begin{abstract}
This paper examines how gender shaped the family of Nancy Hood McGee, who belonged to one of Georgia's antebellum planter families, across four generations. The McGee family had joined the planter class late in the antebellum period, and after the American Civil War they continued to be prosperous farmers in the former cotton belt. The essay proposes that women in the McGee family played a determining role in the family's economic success during this time period. As such, it relates to scholarship on women in the nineteenth-century American South as well as to the role of women within southern families. It also serves as a case study on the importance of the female legacy in family history and genealogy that should be studied as a model in similar instances. McGee women became active in agriculture, business, and education. Research focused on records that revealed information about the family's social and economic development. No diaries and only a few family letters were located, but information transmitted through oral history proved important. Other sources included census records, legal documents such as wills and deeds, newspaper articles, and church records. The research suggested that women in the McGee family played an active role in shaping the family's development across nearly two centuries. This contrasts with popular images of southern women as weak and delicate, although it corresponds with recent research that has highlighted the accomplishments of nineteenth-century women in the American South. Of particular significance is that women in the McGee family kept a record of accomplishment and achievement across several generations of changing circumstances.
\end{abstract}

Keywords: women; gender; south; social; economic; development; family; agriculture; business; education

\section{Preface}

Descendants of the ten children of Sarah Elizabeth Babb Brady (1854-1895) gathered in Georgia in 1990 for a family reunion. Born shortly before the American Civil War began, Brady had belonged to a prominent antebellum family in Harris County, Georgia. She lived through the American Civil War and Reconstruction into the New South. She witnessed the end of slavery, which had sustained her family's wealth, and the constitution of alternative labor systems in its place. By the time she died, the world of her childhood had become the stuff of legend, and the mythology of the "lost cause" would shape the way Americans viewed her lifetime.

More than one hundred people attended the 1990 gathering, and it was the first time in over half a century that so many of Sarah's grandchildren and their families had assembled. One grandson, an elderly veteran of World War II, had travelled from Ontario, Canada to Georgia with his family for the event. It was the first time his Canadian descendants had ever visited the place of their origins. Other descendants had come from Arizona, California, Indiana, Arkansas, and New York and included individuals from every walk of life (Knight 1990).

As the program began, one of Sarah's granddaughters, wearing a dress made by Sarah's daughter Lula nearly a century earlier, stood. She recounted how Sarah and William Brady had lived for all 
of their twenty year marriage on land that had belonged originally to Sarah's McGee grandparents. The land had come to Sarah's mother Concord McGee Babb (1825-1890) following the death of her own mother Nancy Hood McGee (1785-1865), and all ten of the Brady children had been born there- a tangible link between land, lineage, and family legacy. "Now, the legacy of these women has shaped all our lives. It is our common bond", she said, "Let us all acknowledge our foremothers by explaining how we connect to Sarah and her daughters".

The vignette expresses how the role of women had discursively shaped the genealogy narrative of Sarah's descendants, in this case to the extent of minimizing the role of the other families into which they had married. This article explores gender within the McGee family and the way that the McGee women shaped their families and the memory of their heritage (Knight 1990).

\section{Introduction}

Scholars such as Anne Firor Scott, Catherine Clinton, and Elizabeth Fox-Genovese have examined the role of southern women, white and black, in the nineteenth-century United States from many different perspectives. Although the popular images of the dainty "southern belle" and the deferential household slave still survive in the historical imagination, generations of meticulous scholarship have argued that southern women, while they faced legal and societal limitations, found ways of empowering themselves. While these findings have often been based on broad research concentrated within a particular timeframe, especially regarding the southern plantation mistress, they have not often focused on change and continuity within a single family (Scott 1970; Clinton 1992; Clinton 1984; Clinton 1999; Clinton 2000; Fox-Genovese 1988; Rable 1991; Clinton 1995).

This essay extends previous research by focusing on one family to argue that women across five generations became active and assertive shapers of their own and their family's fortunes. It serves as a case study on the importance of the female legacy in family history and genealogy that offers a model for similar studies. Although circumstances changed, the tendency for these women to move beyond the social norms of the times in which they lived remained constant. In this sense, the genealogical perspective enhances our understanding by allowing fresh comparisons and contrasts across generations. Oral recollections from descendants show that the legacy of these women and their activities loomed large in how the family history was preserved and transmitted.

Between 1814, when John McGee married Nancy Hood, and the middle of the twentieth-century, McGee women operated plantations, farms, and other business enterprises. They also became pioneers in education. In many instances, McGee women - rather than their husbands-owned the land and economic resources that supported and sustained their families. As such, they shaped their families' destinies in important ways.

\section{Results}

Research for this study focused on five generations of women in the McGee family. The first generation is represented by family matriarch Nancy Hood McGee (1785-1865). The second generation is represented by Nancy's three daughters, Lodiskey (1819-1842), Jeanette (1823-1909), and Concord (1825-1890). The third generation consisted of twenty-eight granddaughters. The fourth and fifth generations consisted of several dozen great-granddaughters and great-great-granddaughters. Not all of Nancy's female descendants will be examined here, but representative members of the third, fourth, and fifth generations will be discussed.

\subsection{Nancy Hood McGee}

Nancy Hood McGee came from Sussex County, Virginia, to eastern Georgia as a child. The Hood family had been moderately successful tobacco planters in the Virginia Southside, where they had lived since the middle of the seventeenth-century; they had also owned a small number of slaves, although there is no evidence that Nancy's father John Hood brought slaves with him to Georgia. 
In 1814, when she was twenty-nine, Nancy married John C. McGee (1789-1863). ${ }^{1}$ McGee was four years younger than his wife. His father, Josiah Magee, who had settled in Georgia after the revolution, left him a very modest bequest of $\$ 2.00$ when he wrote his will in 1817. The tax records of the senior McGee show that he had owned 160 acres of land and no slaves, had recently remarried and fathered a young child; the bulk of his property was left for her support. ${ }^{2}$

John McGee seems to have owned no property when he married Nancy Hood and to have been without property for several years after marriage. Nancy, however, as a single woman over age twenty-one had drawn 202.5 acres of land in Georgia's 1807 land lottery, and this may have been the genesis of John McGee's landholdings (Graham 2011). By 1821, he owned 200 acres in Columbia County and had drawn two additional tracts, one of 250 acres and another of 490 acres, in the state land lotteries. ${ }^{3}$ By 1825, John had acquired another 200 acres in Columbia County and still owned the other tracts; he also owned four slaves. ${ }^{4}$ He still owned all four tracts in 1830 and 1832, by which time tax records indicated he also owned seven slaves. ${ }^{5}$ In 1833, John purchased two small tracts of 36 and 38 acres, which he promptly resold. ${ }^{6}$

In the 1830s, the McGees relocated from eastern Georgia to the newly settled lands of western Georgia. The area had opened for settlement in 1827 following a land cession from the Creek Indians, and by 1835 the McGees were living in newly settled Harris County. ${ }^{7}$ Over the next two decades, John McGee would acquire interest in nineteen lots of land totaling nearly 4000 acres in Harris County, Georgia. ${ }^{8}$ He also acquired at least 1080 acres of land in South Alabama during these same years (Hahn 1983). By 1840, McGee owned twenty slaves. ${ }^{9}$ By 1850, the value of real estate owned by McGee was estimated at $\$ 6600 .{ }^{10}$ By 1860 , the value of his real estate was estimated at $\$ 11,200$ while the value of his personal property, including the 28 slaves on his Harris County, Georgia, plantation, was estimated at $\$ 31,000 .{ }^{11}$ When McGee died in 1863 , the value of his property, then including at least twenty-nine slaves and more than 2300 acres of land, exceeded $\$ 70,000 .{ }^{12}$

In a single lifetime, John McGee had risen from being a subsistence farmer to being a member of the southern planter aristocracy. Much of his success, however, had been based on the slave-labor economy that dominated throughout the region. In addition to this, the fertile lands of the Chattahoochee River Valley in western Georgia and eastern Alabama, which had until the 1820s been home to Creek Indians, added the rich land that produced the cotton grown on McGee's plantations. Like most

1 Magee, John. Marriage Bond to Nancy Hood. 1814. Columbia County, GA, Loose Marriage Bonds, Microfilm, Georgia State Archives, Morrow, GA.

2 Magee, Josiah, will of. 1817. Columbia Co., GA, Loose Wills, Georgia State Archives, Morrow, GA.

3 McGee, John, tax entry. 1821. Columbia County, GA, Tax Digest, William Wright's District, Microfilm, Georgia State Archives, Morrow, GA.

4 McGee, John, tax entry. 1825. Columbia County, GA, Tax Digest, Dancy Adams's District, Microfilm, Georgia State Archives, Morrow, GA.

5 McGee, John, tax entry. 1830. Columbia County, GA, Tax Digest, Wiley Spivey's District, Microfilm, Georgia State Archives, Morrow, GA; McGee, John, tax entry. 1832. Columbia County, GA, Tax Digest, John Harris's District, Microfilm, Georgia State Archives.

6 Wilson, Elias. Deed to John McGee. 1833. Columbia County, GA, Deed Book (afterwards DB) KK, p. 249, Microfilm, Georgia State Archives, Morrow, GA; McKenzie, John. Deed to John Magee. 1828. Columbia County, GA, DB KK, p. 248, Microfilm, Georgia State Archives, Morrow, GA.

7 McKay, John. Deed to Levi Geer. 1835. Troup County, GA, DB D, p. 315, Troup County Archives, LaGrange, GA.

8 Bass, Mary. Deed to John C. McGee. 1840. Harris County, GA, DB A, p. 627; Culbreath, Beverly. Deed to John McGee. 1842. Harris County, GA, DB D, pp. 280; Newsome, William L. Deed to John McGee. 1845. Harris County, GA, DB F, pp. 431, 478; Manning, J. W., and B. F. Nunnelee, Nancy Hagins, and W. G. McKee. Deeds to John McGee. 1845-1850, Harris County, GA, DB G, pp. 80, 452, 469, 472; Teel, Calvin. Deed to John McGee. 1850. Harris County, GA, DB G, p. 472; Nelson, John, Estate of. Deed to John McGee. 1860. Harris County, GA, DB G, p. 474. All documents in this note are from microfilm at the Georgia State Archives, Morrow, GA.

9 McGehee, John, census entry. 1840. Harris County, GA, Census, p. 242.

10 McGehee, John, census entry. 1850. Harris County, GA, Census, Population Schedule, p. 88, Family Number 564.

11 McGee, John, census entry. 1860. Harris County, GA, Census, Population Schedule, p. 657, Family Number 1063; McGee, John, slave census entry. 1860. Harris County, GA, Census, Slave Schedule, p. 99.

12 McGee, John, Appraisement of Estate. 1863. Harris County, GA, Estate Book 53, pp. 14-17, Microfilm, Georgia State Archives, Morrow, GA. 
white southerners of his day, McGee's wealth was based on the exploitation of those less fortunate than he, a common feature of American society in the Jacksonian era (Howe 2007). Even considering the exploitative nature of economic success in the antebellum South, McGee must have been an enterprising investor to manage a portfolio that grew steadily across five decades.

How much, if anything, Nancy Hood McGee had to do with her husband's growing wealth during this period is debatable. As a married woman, Nancy would have had few legal rights, and there is no evidence that she owned any property independent of her husband after their marriage. The legal principle of coverture meant that Nancy did not have a separate legal identity from her husband John once they married (Salmon 1989). Nancy was, however, literate, and the fact that she did not marry John McGee until she was nearly thirty, by which time, as a single adult woman, she had already become a property-owner herself, suggests that she may have had an independent streak. Family lore also maintains that Nancy was an equal partner who advised her husband on business activities, but no contemporary documentation exists to support the statements (Duke 1984-2002; Rachel 1984-2004; Evans 1984-1996; Sadie 1984-1992). A local history, written in 1884, mentioned Nancy and attributed some of the family's wealth to her: "Mrs. McGhee was of a wealthy family, and at one time before the war her property was assessed at $\$ 100,000 "$ (Cherry 1996). The wording may be significant. Written less than two decades after Nancy's death and an equal time since the end of the Civil War, the author made reference to "her property" rather than to her husband's. Nancy's Hood ancestors had owned land and slaves in Virginia, but no estate division for her father John Hood has been found to document how much property he may have passed to Nancy; the timing of John McGee's property acquisitions soon after his marriage to Nancy suggests, however, that she may have brought property to the marriage-either from inheritance or property, such as the 1807 lottery grant, that she had acquired on her own (Graham 2011). ${ }^{13}$ Secondary evidence suggests that she may also have played a role in increasing that property after marriage. No photograph of John McGee has survived. The daguerreotype of Nancy Hood McGee, believed to have been made in 1862 as her two youngest sons were leaving for war, shows a powerful woman looking forcefully forward the future, both hands grasping a large Bible (Knight 2012). The role Nancy may have played in the economic fortunes of John McGee and the McGee family remains speculative; the activities of her daughters, granddaughters, and great-granddaughters suggests, however, that she may have exerted some positive influence in shaping McGee's growing wealth.

\subsection{Nancy's Daughters}

Nancy Hood and John McGee were the parents of three daughters and six sons. Lodiskey (1819-1842), the oldest daughter, married Mercer Babb in 1837 and died after giving birth to three daughters. Her sister Concord (1825-1890) then married Babb; they had six daughters and four sons. Nancy Jeanette McGee (1823-1908) married Rev. Jesse Revel, a Baptist minister; they were the parents of three daughters, one son, and two other children of unknown gender who died at birth. (See Figure 1 for details.)

Little is known of Lodiskey McGee, the oldest daughter. Her husband Mercer Babb was a well-known builder who specialized in courthouses and other public buildings in western Georgia and eastern Alabama. Babb had a thriving practice and moved frequently during their marriage. He seems to have settled permanently on land adjacent the McGee plantation in Harris County after Lodiskey died. He continued as a builder but operated his business from Harris County. Born about 1799, Babb, who had been married prior to marrying the McGee sisters, was much older than either of them. He died about 1867, just after the Civil War ended, and his widow Concord lived on for another quarter of a century. When Babb died, Concord was left with ten children ranging in age from

13 Hood, Thomas, will of. 1764. Amelia County, VA, Will Book 2X, p. 14, microfilm, Library of Virginia, Richmond, VA; Hood, Nathaniel. Will of. 1779. Sussex County, VA, Estates Book C, p. 379, microfilm, Library of Virginia, Richmond, VA. 
twenty-two years to a few months. Concord, who had recently lost both parents, was left to support her large family alone and, although she and Mercer Babb had had four sons, they were the youngest four of their ten children, and all born between 1857 and $1867 .{ }^{14}$

During her years as a widow, Concord continued to operate the business begun by her husband. Babb had died intestate, and his estate was held together for the support of his minor children. After the youngest child came of age about 1878, however, the estate was still not divided, and Concord continued to manage the property, rent lands and livestock, and operate the lumber-yard that her husband had probably begun for his building activities. By 1890, this property, which had grown under Concord's management, was valued at $\$ 6000$. In addition to this, Concord herself left an estate valued at more than $\$ 3000$. Mercer Babb's estate included 170 acres of land; Concord's included 306 acres, which she managed in her own right and passed on to her children at her death. In addition to land, livestock, and other personal items, Concord's estate included 20,000 feet of sawn lumber for commercial sale. ${ }^{15}$ Descendants would recall Concord as a shrewd manager, a skill she reputedly inherited. In a time of crop liens and tenancy, all ten of her children were able to acquire property from her estate. They also inherited a share of Mercer Babb's property, which was divided also among his two surviving daughters by his marriage to Lodiskey McGee and an older daughter from his first marriage. Concord's descendants would live on the McGee-Babb lands for two more generations before selling the land in the twentieth-century (Duke 1984-2002; Rachel 1984-2004; Evans 1984-1996; Sadie 1984-1992).

Unlike Concord Babb, who lived her adult life near the former McGee Plantation in Harris County, Concord's sister Nancy Jeanette McGee Revel eventually left the area. Jeanette married Jesse Revel, a Baptist minister, and moved first to Talbot County, Georgia, and then to Russell County, Alabama. She lived most of her adult life in Russell and Lee Counties.

Because Jeanette's husband Jesse Revel lived until 1892, Jeanette had less time than her sister Concord to act independently. But there is evidence to suggest that Jeanette may have inherited some of the same financial acumen that seems to have aided her mother and her sister. Jesse Revel had been an orphan with little property. Through hard work, he had acquired both land and cash, but he lost these indirectly as a result of the Panic of 1837. Twice more he built up a comfortable estate only to lose it. Jeanette inherited a portion of the McGee property following her mother's death in 1865, and this seems to have provided the family with greater stability. The land was sold and re-invested in local property on which Jesse and Jeanette lived for the final years of his life. Following his death, Jeanette moved from the country first to Columbus, Georgia, and then to Birmingham, Alabama, to assist a widowed daughter. She died there in 1908 at the age of 85. Descendants would credit the McGee inheritance for providing much needed financial assistance and Jeanette's own skillful management for maintaining and developing the property they purchased as a result (Cherry 1996; Self 1998). ${ }^{16}$

14 Babb, Mercer, census entry. 1860. Harris County, GA, Census, Population Schedule, p. 647; Babb, Mercer, Inventory and Account of. 1867a. Harris Co., GA, Estate Book 55, pp. 240-45; Babb, Mercer, Probate of. 1867b. Harris County, GA, Probate Minute Book 33, p. 73; Babb, Mercer, and Concord Babb, Inventory and Account of. 1890. Harris County, GA, Estate Book 34, pp. 350-65; Babb, Mercer, orphans, guardianship of. 1870. Harris County, GA, Estate Book 55, p. 440. All Harris County, GA, legal documents cited in this note are from microfilm, Georgia State Archives, Morrow, GA.

15 Babb, Mercer, and Concord Babb, Inventory and Account of. 1890. Harris County, GA, Estate Book 34, pp. 350-65, Microfilm, Georgia State Archives, Morrow, GA.

16 Revel, Jesse, and N.J. Deed to Needom Marsh. 1875. Coffee County, AL, DB I, p. 795; Revel, J. L., and N. J. Revel. Deed to John McGee, Jr. 1875. Coffee County, AL, DB Y, p. 33; Revel, Jesse, and Nancy J. Revel. Deed to J. A. Scroggins. 1876. Lee County, AL, DB OO, p. 343; Revel, Jesse, and Janet Revel. Deed to John F. Rutledge, Jr. 1885. Lee County, AL, DB A-1, p. 286; 1908. Nancy J. Revel. Birmingham ( $A L)$ News, May 13, p. 1; Revel, Jesse, Ordination of. 1846. Bethany Baptist Church Minutes, Chipley Historical Center, Pine Mountain, GA. Coffee County, AL, deeds are housed at the Coffee County, AL, Courthouse, Elba, AL. Lee County, AL, deeds are housed at the Lee County, AL, Courthouse, Opelika, AL. 


\subsection{Nancy's Granddaughters.}

Nancy Hood and John McGee had twenty-six granddaughters. Several died as children or infants. Son Mark McGee's only daughter, who was named Sarah, died of a childhood illness. Two sons had no daughters. Son John fathered seven daughters, but four of the seven died in a fever epidemic as children. James Turner had two daughters, Lodiskey had three, Concord had six, and Alfred had seven.

Of the descendants of the three McGee sisters, the common theme was that the McGee inheritance came from mother to daughter and helped provide the basis of the family's economic stability. Because of this, the women, not the men, were sometimes the landowners; in other cases, while the men legally purchased property in their own names, they did so with funds their wives had inherited. In the family of Edward Solomon Hand and Eliza Babb Hand, for instance, the Hand fortunes were augmented by the inheritance from Eliza's father Mercer Babb after her aunt and stepmother Concord died. Earlier, Eliza had also received a direct inheritance from her McGee grandparents that came to her by virtue of the fact that her mother Lodiskey had died young. In Eliza's case, her unmarried sister Caroline lived with her for most of her long life. Eliza and Caroline pooled resources that helped purchase the family property, and all members of the family worked the lands. Edward Solomon Hand was remembered as a wise planner, but the contributions of Eliza and Caroline were recognized in the family's oral history. Hand family tradition, in fact, holds that it was the money Eliza and Caroline inherited that purchased not only the farm of Edward Solomon Hand but the farms on which his elderly parents and four siblings lived with their families. A similar story existed among the descendants of Concord Babb's daughter Sarah Babb Brady. The land on which the Brady family lived, although it was registered in Sarah's husband's name, had been an inheritance from her mother that had once belonged to her McGee grandparents. It was recognized as McGee and Babb, not Brady, property that had come to the family through the efforts of Concord and her daughter Sarah. Similarly, the Revel family recognized that the McGee inheritance had provided the financial wherewithal that kept the family afloat at a critical moment (Duke 1984-2002; Rachel 1984-2004; Evans 1984-1996; Sadie 1984-1992; Self 1998; Smith 2001; Hand 2001).

Several of Nancy McGee's granddaughters left the area of the Deep South into which they were born. Granddaughter Julia Ann McGee Goolsby settled with her husband Adoniram Judson Goolsby in Hopkins County, Texas, just east of Dallas. Her sister Martha McGee Johnson had settled near Fort Smith, in Sebastian County, Arkansas, with her husband William Johnson about the same time. Their parents and other siblings remained behind in Coffee County, Alabama. Few details of their early lives are known, but Martha's granddaughter remembered her as a wise financial manager whose management of the family fortunes provided a secure footing upon which her children and grandchildren would build (McElroy 2004).

The three daughters of Jeanette McGee and Jesse Revel all became important figures in shaping their families. Virginia Lacey Revel Bennett moved from east central Alabama to Birmingham, where her son A. V. Bennett became Fire Chief. She later moved with him to Pittsburgh, Pennsylvania, where he became director of Western Pennsylvania Traction and Water Power Company and Vice President of Allegheny Pittsburgh Coal Company. Virginia died in Pittsburgh in 1923; Bennett family history credited her with shaping the life and career of her son, who became a leading business figure in Pittsburgh (Slaughter 2001). ${ }^{17}$ Mary Cornelia Revel married Henry Clay Dudley, a Confederate veteran and prosperous merchant in Russell County, Alabama. Mary was Dudley's second wife and the stepmother to his older children and the mother of two surviving children, one of whom became a merchant in Birmingham and the other of whom became a college professor in Atlanta. Again, Dudley family history credited Mary's influence as decisive in shaping the lives and careers of her children and stepchildren (Dudley 1999). Sarah Theresa, the third Revel daughter, married Irwin S. Johnson, who was twenty years her senior. Irvin was an enterprising citizen and acquired

17 1923. Virginia R. Bennett. Birmingham (AL) Age Herald, November 27, p. 1. 
substantial property of his own, but he died in 1891 and left Sarah with ten young children (Cherry 1996; Brasch and Brasch 1999). ${ }^{18}$ Following his death, Sarah moved from the 860 -acre farm in rural Alabama to Columbus, Georgia, a bustling city on the nearby Chattahoochee River, where she was to become "one of the best known women". ${ }^{19}$ She lived there as a widow for nearly a quarter of a century. Alone, "she took up the battle of life, and fought as bravely as any warrior in any battle ever did. Ten little children to care for was one great incentive to work, and these she had reared to young manhood and young womanhood successfully". ${ }^{20}$ Sarah managed the farm and rented portions of the property to tenants from her Columbus residence until she died in 1913; her ten children would maintain the property until 1949, when the last of the acreage was sold. Her descendants recalled her as a remarkable woman who not only was an effective financial manager but who also played an important motivational role in shaping the lives and careers of her nine daughters and one son (Cherry 1996; Brasch and Brasch 1999; Ellis 1999-2001). ${ }^{21}$

The lives of Nancy Hood McGee's twenty-six granddaughters differed from one another in many ways, but a common theme-whether they were rural or urban dwellers, living near their birthplace or far from it-seems to have been that they played an important role in shaping the economic fortunes of their families as well as in molding their offspring and preparing them for success. Their contributions have been remembered in oral family history and transmitted across generations into the twenty-first century. This was true of Eliza Babb Hand and her sister Caroline, whose inheritance helped purchase the Hand family farms in Cleburne County, Alabama. It was also true of Sarah Revel Johnson, who, as a widow, was able to manage family properties and rear her young offspring with little outside interference. This essay now turns to the next generation of McGee women.

\subsection{Nancy's Great-granddaughters and Great-great-granddaughters.}

Nancy's twenty-six granddaughters produced dozens of great-granddaughters and great-great-granddaughters, whose lives spanned much of the twentieth-century. They would live throughout the United States, from New York City to Los Angeles, and in several foreign countries. The contributions of the McGee women would play an important role in shaping their own family histories. The following paragraphs will discuss the remarkable lives of several of Nancy's great-granddaughters and great-great-granddaughters (Duke 1984-2002; Ellis 1999-2001; Brasch and Brasch 1999; Nancy 1999; Lopez-Unger 1999; Frapart 2000).

18 Joy, Etoile Johnson and Johnson, Irwin S., Heirs of. Deeds to William Johnson. 1914-1920. Lee County, AL, DB 130, pp. 367-68, 369, 370, 385; Slaughter, Susie, and Alpheus B. Slaughter. Deed to William R. Johnson. 1914. Lee County, AL, DB 111, p. 250; Schnell, Sebie. Deed to William R. Johnson. 1916. Lee County, AL, DB 115, p. 32; Johnson, Irwin S., Heirs of. Deed to William R. Johnson. 1922. Lee County, AL, DB 137, pp. 7, 191; Browning, John A., and Mary F. Browning. Deed to William R. Johnson. 1914. Lee County, AL, DB 164, p. 346; Davis, Dan B., and Jeanette Davis. Deed to William R. Johnson. 1914. Lee County, AL, DB 108, p. 133; McCoy, Jett T. Deed to Irwin S. Johnson. 1868. Lee County, AL, DB 300, p. 302; Irwin S. Johnson and Sarah Theresa Revel. Family Record, 1829-1913. Owned by Lance and Julie Brasch, Annapolis, MD; 1913. Mrs. Johnson Died Tuesday: Funeral Takes Place Wednesday Morning-Had Hundreds of Friends. Columbus (GA) Ledger, January 21, p. 3; 1913. Eulogy for Sarah T. Johnson. Columbus (GA) Enquirer-Sun, January 23, p. 1. All Lee County, $\mathrm{AL}$, deeds are housed in the Lee County, AL, Courthouse, Opelika, AL.

19 1913. Mrs. Johnson Died Tuesday: Funeral Takes Place Wednesday Morning-Had Hundreds of Friends. Columbus (GA) Ledger, January 21, p. 3.

20 1913. Mrs. Johnson Died Tuesday: Funeral Takes Place Wednesday Morning-Had Hundreds of Friends. Columbus (GA) Ledger, January 21 , p. 3.

21 Joy, Etoile Johnson and Johnson, Irwin S., Heirs of. Deeds to William Johnson. 1914-1920. Lee County, AL, DB 130, pp. 367-68, 369, 370, 385; Slaughter, Susie, and Alpheus B. Slaughter. Deed to William R. Johnson. 1914. Lee County, AL, DB 111, p. 250; Schnell, Sebie. Deed to William Russell Johnson. 1916. Lee County, AL, DB 115, p. 32; Johnson, Irwin S., Heirs of. Deed to William R. Johnson. 1922. Lee County, AL, DB 137, pp. 7, 191; Browning, John A., and Mary F. Browning. Deed to William R. Johnson. 1914. Lee County, AL, DB 164, p. 346; Davis, Dan B., and Jeanette Davis. Deed to William R. Johnson. 1914. Lee County, AL, DB 108, p. 133; McCoy, Jett T. Deed to Irwin S. Johnson. 1868. Lee County, AL, DB 300, p. 302; Irwin S. Johnson and Sarah Theresa Revel. Family Record, 1829-1913. Owned by Lance and Julie Brasch, Annapolis, MD; Mrs. Johnson Died Tuesday: Funeral Takes Place Wednesday Morning-Had Hundreds of Friends. 1913. Columbus (GA) Ledger, January 21, p. 3; 1913. Eulogy for Sarah T. Johnson. Columbus (GA) Enquirer-Sun, January 23, p. 1. All Lee County, $\mathrm{AL}$, deeds are housed in the Lee County, AL, Courthouse, Opelika, AL. 
Education proved an important theme among many of Nancy's descendants. Nancy's grandson Rev. Mark Thomas McGee became a circuit-riding Methodist minister but died at age forty-one, leaving a large family. Two of his daughters, Mattie Mark McGee and Eunice Hill McGee, who were small children when their father died, overcame early disadvantages to attend college and become prominent educators in West Georgia. Mattie Mark McGee became a teacher and school principal in LaGrange, Georgia, where she "yielded a valuable and immeasurable influence among the youth of the city". ${ }^{22}$ She taught for twenty-six years and served as principal for eighteen. In addition to her work in education, she was active in the city's civic affairs. Following her death in 1935, the Mattie McGee Memorial Committee was formed "to establish a fitting memorial to a woman who made definite and invaluable contributions to the educational, civic, religious and social life of LaGrange". ${ }^{23}$ The committee included educators, industrialists, and civic leaders. The result was the creation of the Mattie McGee Memorial Library, which served the community in which McGee worked for several decades. ${ }^{24}$ Mattie's sister Eunice Hill McGee attended Peabody College in Nashville before becoming a public school teacher; she finished her career at Eastern Carolina University, where she was a counselor, taught in the teacher education program, and directed one of the dormitories for many years (Vogel 1959). Beachye McGee Hopkins, whose father Joseph D. McGee was Mark Thomas McGee's brother, had a career in education in Harris County, Georgia, where she also served for several years during the Depression as Federal Director for Public Welfare. ${ }^{25}$

Many of the granddaughters and great-granddaughters of Nancy's other children also pursued careers in education. Several of her son Milton's granddaughters and great-granddaughters became educators in Texas and California (Knight 2000a). Nancy's son Alfred McGee was a school teacher himself and at one time served as Superintendent of Education for Coffee County, Alabama. Educational pursuits figured significantly among his descendants. Several of his granddaughters became public school teachers, and his granddaughter Hattie Rae Woolsey retired as Dean of Nursing at Jefferson-Hillman Nursing School in Birmingham (Knight 2000b). Similar patterns held true for descendants of James Turner McGee, John McGee, Jr., Concord McGee Babb, and Lodiskey McGee Babb. Together, more than a dozen of their granddaughters and great-granddaughters pursued careers in education at the elementary, secondary, and post-secondary levels (Knight 2000c; Knight 2000d; Knight 2000e).

Beyond educational endeavors, however, the great-granddaughters and great-greatgranddaughters of Nancy Hood McGee also achieved success in business and civic affairs. In this instance, the family of Nancy's granddaughter Sarah Theresa Revel Johnson offers a particularly instructive example. Widowed early, Sarah Theresa reared nine daughters and one son alone. The children were born between 1870 and 1892. Her son William Johnson, the fifth child, eventually took over the family farm as an adult, but several of William's nine sisters pursued careers in business. As adults, the Johnson sisters lived in Georgia, Alabama, Florida, North Carolina, New Jersey, Pennsylvania, and New York. The daughters were engaged in a number of business ventures, ranging from landscaping and design to real estate and the clothing trade. The most successful was Irwin S. Johnson Morrison (1887-1969). Irwin, who was named for her father, began her professional life as a clerk for Joseph A. Kirven's retail department store in Columbus, Georgia, in 1906 (Polk 1906). When she was in her thirties, Morrison moved to New York City and traveled extensively in France. She later relocated to Daytona Beach, Florida, where she opened Irwin's Dress Shop in 1931. She would operate Irwin's for nearly four decades, during which time it became an exclusive shopping location for wealthy families along Florida's Atlantic coast. In addition to her work at Irwin's, Morrison also became a personal buyer for a wealthy clientele, among them the Dorrance family of Campbell's Soup

\footnotetext{
1935. M'Gee, Miss M. M. Beloved Teacher, Dies Early Today. LaGrange (GA) Daily News, October 16, p. 1.

1939. McGee, Mattie Mark. LaGrange (GA) Daily News, February 4, p. 1.

1939. McGee, Mattie Mark. LaGrange (GA) Daily News, February 4, p. 1.

1940. Beachye Hopkins. Columbus (GA) Enquirer, March 22, p. 8.
} 
fame, whom Morrison had originally befriended while living in New York. Irwin Johnson Morrison became legendary among the wealthy and fashionable along the Florida coast, and Irwin's became a Daytona institution that continued to be operated by Morrison's family for many years after her death (Brasch and Brasch 1999; Lopez-Unger 1999; Ellis 1999-2001). ${ }^{26}$

The Johnson sisters and their Bennett cousins-all great-grandchildren of Nancy Hood McGee-established important connections throughout Pennsylvania, New Jersey, and New York. These connections aided the next generation of the family, several of whom remained in this region throughout their lives. Lenora Susan Slaughter (1906-2000) was a daughter of Susan Johnson Slaughter and a niece of Irwin Johnson Morrison. Slaughter was born in Florida and began her professional career during the Great Depression working for the St. Petersburg Chamber of Commerce. In 1935, she was hired to assist with the Miss America Pageant in Atlantic City, New Jersey. The pageant, which had been created in 1921, had lost its financial backing in 1927. It was revived in 1935 when Slaughter, using marketing experience she had developed in St. Petersburg, joined the team. In 1938, she became the pageant's Executive Director. According to the Atlantic City Museum, "The Pageant did regain sure financial footing in 1940 when the official title was changed to the Miss America Pageant and its venue became Convention Hall. During the 1940s, the national executive director Lenora Slaughter shaped the pageant into the American icon we know it to be today. Full state representation was achieved and the scholarship program and a judging category based on personal interviews were added. The first nationally televised broadcast of the Miss America Pageant took place on 11 September 1954 to a viewing audience of 27 million. The following year the pageant introduced Bert Parks and the theme song 'There She Is-Miss America'. The rest is history" (Atlantic City Museum; Marquis 1961; Marquis 1964; Frapart 2000; Brasch and Brasch 1999; Ellis 1999-2001).

Lenora S. Slaughter-“a strong-willed woman accustomed to getting her way"—is credited with having transformed the Miss America Pageant from a small-town affair to the national competition that it is today, imbuing it with attention to the many aspects of character, spirit, talent, and beauty that the title now represents (Yockel 2001; Atlantic City Museum). For the duration of the three decades in which she served as its Executive Director, "Lenora was the pageant". After her marriage in 1944 to Bradford Frapart, a successful managerial officer, the wife-husband team restructured the pageant's finances, leaving it on sound financial footing at their retirement and ensuring its success for decades to come. Slaughter's influence has affected millions of Americans and is still felt today, nearly a century after it was first established (Atlantic City Museum; Marquis 1961; Marquis 1964; Frapart 2000; Yockel 2001).

\subsection{Summary}

The examples discussed here suggest that Nancy Hood McGee, her daughters, her granddaughters, her great-granddaughters, and her great-great-granddaughters were accomplished and active women who, across several generations, exceeded contemporary societal expectations for women in significant ways. Later generations of Nancy's female descendants have continued this pattern, but they have done so in an era in which women in general experienced greater opportunities. The women discussed here were all born between the end of the American Revolution and the beginning of the first world war. On an individual basis, their activities and accomplishments-while beyond those accessible to many women - might not seem particularly unique, but, when placed in the context of a single family across several generations, they suggest an extraordinary pattern of behavior. Beyond gender history and in terms of family history and genealogy more generally, it is also significant that these women were all remembered and celebrated within the oral histories of their families, as was their connection to the family of Nancy Hood McGee. This preserved historical memory transcended time — extending from the nineteenth into the twenty-first century—and distance,

26 1969. Mrs. I. Morrison, Dead at 81. The Daytona Beach (FL) News-Journal, June 22, p. 1. 
stretching along the Atlantic seaboard from New York to Florida and westward to the Pacific coast. And in every instance, it was the legacy of these outstanding women which was remembered.

\section{Discussion}

In a 1992 essay, Catherine Clinton remarked on the "malignant neglect" with which the history of women in the southern United States had traditionally been approached. Pioneering historians of southern women like Anne Firor Scott had already worked to rectify the imbalance of scholarship addressing southern women, but in the 1980s, 1990s, and early 2000s Clinton herself, Elizabeth Fox-Genovese, George Rable, Drew Gilpin Faust, and others produced important monographs on nineteenth century southern women, especially those of the Civil War era (Scott 1970; Clinton 1992; Clinton 1984; Clinton 1999; Clinton 2000; Fox-Genovese 1988; Rable 1991; Clinton 1995; Faust 2004). Important new scholarship has also emerged focusing on Georgia women. Andrew Lannen's history of colonial Georgia addressed the legal status of colonial women, especially in matters of inheritance (Lannen 2002). LeeAnn Whites's The Civil War as a Crisis in Gender focused on Augusta, Georgia, from the beginning of the war to 1890 (Whites 2000). More recently, the two volume set of essays edited by Ann Short Chirhart, Betty Wood, and Kathleen Ann Clark, Georgia Women: Their Lives and Times has explored the lives of Georgia women from the colonial times throughout the twentieth century through the lens of individual biography. Such characters as Mary Musgrove, Nancy Hart, Fanny Kemble, and Eliza Frances Andrews come to life through the scholarly essays presented in the series (Chirhart and Wood 2009; Clark and Chirhart 2014). Much—although by no means all—of this work has tended to focus on elite southern white women, while an impressive array of scholarship has addressed the experiences of slave women throughout the South more generally (Fox-Genovese 1988; Stevenson 1997; Camp 2004; White 1999; Berry 2007; Berry and Harris 2014; Berry and Alford 2012).

Scholarship on the middle range of southern women has been more limited (Bernhard et al. 1994), and much of recent scholarship has focused on the more public role of southern women in social movements, such as women's suffrage and political organization (Turner 2008; Wheeler 1993). For the last three decades of her life, Nancy Hood McGee was the wife of a southern planter, and the wealth which she and her husband John McGee accumulated was based on slave labor. With his modest origins and "self-made" status, however, John McGee had risen into the planter ranks at midlife, and the McGees held planter status only for the final decades of the plantation South. After the Civil War, the family retained lands—-which, as expressed above, were significant—but the McGees would have been considered prosperous farmers rather than aristocrats on the one hand or tenants, sharecroppers, or "poor whites" on the other. The lives of such women have not been a major focus of scholarship; neither have social, cultural, and demographic patterns within their families across time (Boney 1984; Reed 1986; Kenneth 1991; Tindall 1967; Boney 2004).

Nancy Hood McGee and her female descendants offer only one example, but it is an instructive one when compared against the larger historiography of the period (Chirhart and Wood 2009; Clark and Chirhart 2014; Whites 2000; Bernhard et al. 1994; Turner 2008; Wheeler 1993; Simms 2017). Across more than four generations they were active in agriculture, business, education, and civic life. Some, like Eliza Babb Hand and Sarah Babb Brady, played an important role in providing the physical resources that helped support their families. Others, like Concord McGee Babb, her niece Sarah Theresa Revel Johnson, and her great-niece Irwin Johnson Morrison, managed business enterprises. Mattie Mark McGee and Eunice Hill McGee became well-known educators and civic leaders; their influence in the mill villages of LaGrange, Georgia, helped provide upward mobility for generations of factory children. Through her work with the Miss America Pageant, Lenora S. Slaughter combined business savvy and a commitment to education and civic values to influence millions of Americans.

\section{Materials and Methods}

Research focused on many different sources. Oral history gathered over the course of more than two decades provided valuable information about personal activities, including family recollections 
about many of the women involved. To gather this information, the author initially focused on McGee descendants still living in western Georgia and eastern Alabama. Later, he systematically tracked the descendants of the nine children of Nancy Hood McGee into the twentieth century, interviewing them in person, by telephone, by e-mail, and through correspondence. Research questions focused on various issues, including wealth, social standing, occupation, education, family size, gender roles, migration patterns, the preservation and transmission of historical memory, ideas about kinship and identity, and genealogical relationships themselves. Both men and women were interviewed and asked similar questions. Cumulatively, this proved to be a rich source of information from which a consistent pattern of women's activity and activism-recognized by both male and female interviewees-soon emerged.

Equipped with valuable information from living descendants, the author then followed a prosopographical methodology focusing on family reconstitution and analysis that allowed for comparison and contrast across generations. The research methodology borrowed from the work of John Demos, particularly in Entertaining Satan and The Unredeemed Captive, as well as work pioneered by the Prosopography Research Unit at Oxford University (Demos 1984; Demos 1994; Modern History Research Unit, University of Oxford).

Key sources for this research included legal records created at the federal, state, and county level. Federal census records for Columbia County, Georgia, Harris County, Georgia, and other locations in which descendants later lived helped provide the family's demographic outlines, including information about occupation, education, and wealth. Legal records-particularly wills, estate inventories, estate divisions, land deeds, and marriage records-documented not only the family lineage but also provided valuable data about estate size, land ownership, inheritance patterns, and the economic value of real and personal property. Newspaper articles, especially obituaries, often supplemented this bare-bones data with personal information about lives and accomplishments. Church records provided details of church membership and sometimes church activities.

\section{Conclusions}

Nancy Hood McGee and her female descendants were able and accomplished southern women of the nineteenth and twentieth centuries. They helped shape the fortunes of the McGee family and the other families into which they married in important ways. Modern researchers might discuss whether this was a case of nature-perhaps rooted in genetic dispositions coded within autosomal DNA—or of nurture, the by-product of a family culture that trained women to achieve and accomplish. Whatever the source, however, the activities of women within the McGee family support an interpretation of southern women in the nineteenth and early twentieth centuries that sees them not as passive conduits of family history and lineage but instead as active participants in molding the family's fortune. These finding are consistent with the overall tenor of recent academic scholarship that portrays women of the American South as active shapers of their own destinies, albeit against often considerable resistance. Contextualizing women's activity within a single family of middling rank across several generations, however, offers opportunities for fruitful comparison and contrast should additional studies of this sort emerge in the future.

In terms of gender's influence on genealogy narratives, it is notable that among the descendants of Nancy Hood McGee the activities and accomplishments of the McGee women dominated oral accounts of the McGee family's history. Both male and female interviewees recognized and discussed the successes of Nancy's daughters, granddaughters, and great-granddaughters (Duke 1984-2002; Rachel 1984-2004; Sadie 1984-1992; Evans 1984-1996; Self 1998; Smith 2001; Hand 2001; McElroy 2004; Slaughter 2001; Dudley 1999; Brasch and Brasch 1999; Nancy 1999; Lopez-Unger 1999; Frapart 2000; Teaver 1998-2002; Ellis 1999-2001; Champion and Champion 1984-2004). In addition to shaping the family's history, however, women also served as the primary keepers of the family's collective memory. One of Nancy's great-great-granddaughters, in relating stories from the 1860s told to her in the 1920s and 1930s, described herself as a "bridge" between the past and the present (Duke 1984-2002). She 
reported a pattern of transference of information that primarily followed female paths from mother to daughter and aunt to niece. According to the story she related, Sarah Babb Brady, as she lay dying in 1895 , assembled her five daughters at her bedside and told them stories of her family's past. The last of these daughters died in 1969, aged eighty-eight (Knight 2000e). The last of their daughters died in 2010, aged ninety-two; in her youth, she had known women who knew Nancy Hood McGee personally (Litesey 2010). Descendants of each of Nancy's daughters related similar tales of how the family's historical memory was translated to the present generation. Family gatherings, formal and informal, became opportunities for discursively reconstructing the family's heritage by passing along these stories (Duke 1984-2002; Rachel 1984-2004; Evans 1984-1996; Sadie 1984-1992; Self 1998; Smith 2001; Hand 2001; Nancy 1999; Teaver 1998-2002; Ellis 1999-2001; Champion and Champion 1984-2004). This pattern held true among descendants living in different parts of the United States and Canada, many of whom traced their connection to the McGee family through a mother, a grandmother, or a great-grandmother. These women passed along not only lineage but also of a legacy of women's activity and accomplishment that shaped successive generations and how they preserved and transmitted their family's heritage.

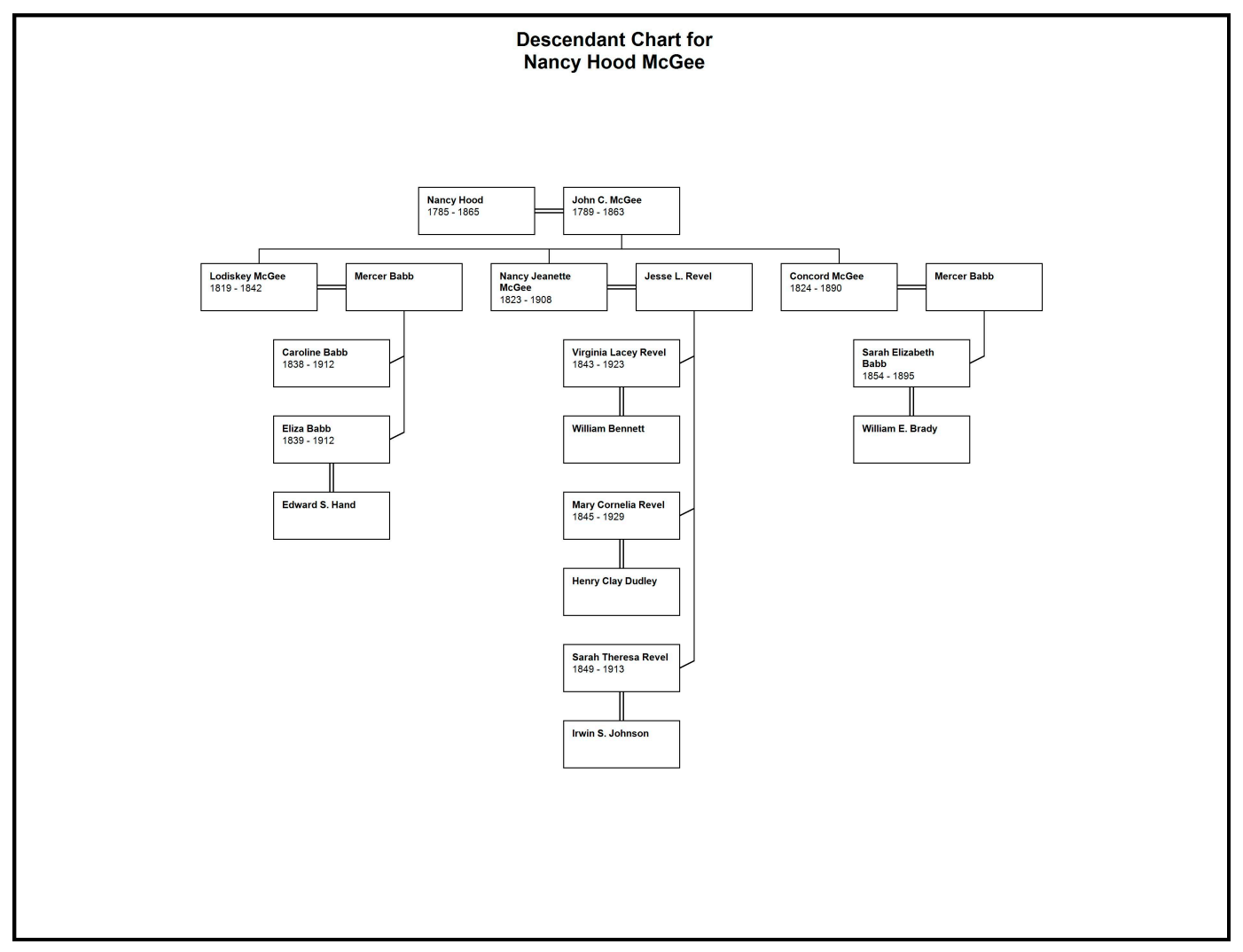

Figure 1. Selected descendants of Nancy Hood McGee (1785-1865).

Conflicts of Interest: The author declares no conflict of interest.

\section{References}

Atlantic City Museum. Miss America Pageant. Available online: http:/ /www.nj.com/acmuseum/msamerica.html (accessed on 1 February 2000).

Brasch, Lance, and Brasch Julie. e-mail message to author, 15 July 1999.

Berry, Daina. 2007. Swing the Sickle for the Harvest Is Ripe: Gender and Slavery in Antebellum Georgia. Champaign: University of Illinois Press.

Daina R. Berry, and Leslie M. Harris, eds. 2014. Slavery and Freedom in Savannah. Athens: University of Georgia Press. 
Daina R. Berry, and Deleso A. Alford, eds. 2012. Enslaved Women in America: An Encyclopedia. Santa Barbara: Greenwood Press.

Virginia Bernhard, Betty Brandon, Elizabeth Fox-Genovese, Theda Perdue, and Elizabeth H. Turner, eds. 1994. Hidden Histories of Women in the New South. Columbia: University of Missouri Press.

Boney, F. Nash. 1984. Southerners All. Macon: Mercer University Press. Boney 1984 is a classic work that attempts to bridge social divides in the South.

Boney, F. N. 2004. Poor Whites, New Georgia Encyclopedia. Available online: http:/ /www.georgiaencyclopedia. org/articles/history-archaeology/poor-whites (accessed on 27 May 2017).

Coleman Kenneth, ed. 1991. A History of Georgia, 2nd ed. Athens: University of Georgia Press.

Cherry, Francis Lafayette. 1996. The History of Opelika and Her Agricultural Tributary, rev. ed. Opelika: The Genealogical Society of East Alabama. First published in 1884.

Clinton, Catherine. 1992. In Search of Southern Women's History: The Current State of Academic Publishing. The Georgia Historical Quarterly 76: 420-27.

Clinton, Catherine. 1984. The Plantation Mistress: Woman's World in the Old South. New York: Pantheon Books.

Clinton, Catherine. 1999. The Other Civil War South: American Women in the Nineteenth Century. New York: Hill and Wang.

Clinton, Catherine. 2000. Southern Families at War: Loyalty and Conflict in the Civil War South. Oxford: Oxford University Press.

Ann Short Chirhart, and Betty Wood, eds. 2009. Georgia Women: Their Lives and Times. Athens: University of Georgia Press, vol. 1.

Kathleen Ann Clark, and Ann Chirhart, eds. 2014. Georgia Women: Their Lives and Times. Athens: University of Georgia Press, vol. 2.

Clinton, Catherine. 1995. Tara Revisited: Women, War, and the Plantation Legend. New York: Abbeville Press.

Camp, Stephanie M. H. 2004. Closer to Freedom: Enslaved Women E Everyday Resistance in the Plantation South. Chapel Hill: The University of North Carolina Press.

Champion, Hubert, and Lillian D. Champion. 1984-2004. Interviews by author, Pine Mountain, GA, USA.

Demos, John. 1984. Entertaining Satan: Witchcraft and the Culture of Early New England. Oxford: Oxford University Press.

Demos, John. 1994. The Unredeemed Captive: A Family Story from Early America. New York: Alfred A. Knopf.

Duke, Hazel Evans. 1984-2002. Interview by author, LaGrange, GA, USA.

Dudley, Artie Blalock. 1999. Interview by author. Telephone interview, Phenix City. AL, November 5.

Evans, William C. 1984-1996. Interviews by author, LaGrange, GA, USA.

Ellis, Judy Reid. 1999-2001. Interviews by author. Telephone interview. LaGrange, GA, USA.

Frapart, Brad. 2000. Interview by author. Telephone interview. Tamarac, FL, USA, February 1.

Fox-Genovese, Elizabeth. 1988. Within the Plantation Household: Black and White Women of the Old South. Chapel Hill: University of North Carolina Press.

Faust, Drew Gilpin. 2004. Mothers of Invention: Women of the Slaveholding South in the American Civil War. Chapel Hill: University of North Carolina Press.

Graham, Paul K. 2011. 1807 Georgia Land Lottery Fortunate Drawers and Grantees. Decatur: The Genealogy Company. Hahn, Marilyn Davis. 1983. Old St. Stephens' Land Office Records. Easley: Southern Historical Press.

Hand, Bill. 2001. Interviews by author, Ranburne, AL, USA, September 22.

Howe, Daniel Walker. 2007. What God Hath Wrought: The Transformation of America, 1815-1848. Oxford: Oxford University Press.

Howard, Sadie Evans . 1984-1992. Interviews by author, LaGrange, GA, USA.

Knight, Thomas D. 2000a. Descendants of William Milton McGee. LaGrange: Family Tree Press, pp. 22, 24, 63, 66, 67, $68,69,73,75,76,77$.

Knight, Thomas D. 2000b. Descendants of Alfred McGee. LaGrange: Family Tree Press, pp. 2, 19, 22, 94, $254,259$.

Knight, Thomas D. 2000c. Descendants of John McGee, Jr. LaGrange: Family Tree Press, p. 58.

Knight, Thomas D. 2000d. Descendants of Lodiskey McGee Babb. LaGrange: Family Tree Press, pp. 27, 30.

Knight, Thomas D. 2000e. Descendants of Concord McGee Babb. LaGrange: Family Tree Press, pp. 99, 113, 115, 132.

Knight, Thomas Daniel. 1990. An American Portrait: The Family of William Easterland Brady and Sarah Elizabeth Babb. LaGrange: Family Tree Publications.

Knight, Thomas Daniel. 2012. The Other Scotch-Irish: A Six Generation Analysis of Social and Economic Change in the George Magee Family of Maryland and Georgia, 1683-1865. The Journal of Scotch-Irish Studies 3: 12-46. 
Lopez-Unger, Janet. 1999. e-mail message to author. Pine Mountain, GA, USA, 25 June 1999.

Litesey, Lester C. 2010. Obituary of Rachael Ramey. Available online: http:/ / www.liteseyfh.com/fh/obituaries / obituary.cfm?o_id=559660\&fh_id=12186 (accessed on 26 June 2017).

Lannen, Andrew C. 2002. Liberty and Authority in Colonial Georgia, 1717-1776. Ph.D. Dissertation, Louisiana State University, Baton Rouge, LA, USA. Available online: http:/ / digitalcommons.lsu.edu/gradschool_ dissertations /3270/ (accessed on 14 June 2017).

McElroy, Martha Johnson. 2004. Interview by author. Telephone interview. Atlanta, GA, USA, March 18.

Marquis, A.N. 1964. Who's Who of American Women, 3rd ed. Chicago: Marquis Who's Who, p. 934.

Modern History Research Unit, University of Oxford. Prosopography Research. Available online: http:// prosopography.modhist.ox.ac.uk/ (accessed on 27 May 2017). The author was fortunate enough to attend two conferences hosted by the Prosopography Research Unit at Oxford University in the early 2000s.

Marquis, A.N. 1961. Who's Who of American Women, 2nd ed. Chicago: Marquis Who's Who, p. 909.

Polk, R.L. 1906. R. L. Polk E Co.'s Columbus, GA., City Directory. Detroit and Columbus: R. L. Polk \& Co, p. 283.

Nancy, Reynolds. 1999. e-mail message to author. June 5. Salem, OR. Reynolds related family stories about the McGee family that had traveled from Harris Co., GA, to Gonzalez Co., TX, to Orange County, CA, through the line of Milton McGee, whose family settled in Texas after the Civil War. The stories passed from Nancy McGee Steubing to her daughter Exa Steubing Cookson to her daughters and granddaughters.

Rable, George C. 1991. Civil Wars: Women and the Crisis of Southern Nationalism. Champaign: University of Illinois Press. Rachel, Evans Ramey. 1984-2004. Interview by author, LaGrange, GA, USA.

Reed, John Shelton. 1986. Southern Folk, Plain and Fancy: Native White Social Types. Athens: University of Georgia Press. Like Boney 1984, Reed 1986 is a classic work that deals with social divides in the South.

Self, Mattie James Revel. 1998. Interview by author, Phenix City, AL, USA, August 15.

Smith, Grace Whitman. 2001. Interview by author, Ranburne, AL, USA, September 22.

Slaughter, William. 2001. Interview by author, Telephone interview. Bluffton, SC, USA, October 1.

Scott, Anne Firor. 1970. The Southern Lady: From Pedestal to Politics, 1830-1930. Chicago: University of Chicago Press. Stevenson, Brenda E. 1997. Life in Black \& White: Family and Community in the Slave South. Oxford: Oxford University Press.

Simms, Anastatia. 2017. The Power of Femininity in the New South: Women's Organizations and Politics in North Carolina, 1880-1930. Columbia: University of South Carolina Press.

Salmon, Marilyn. 1989. Women and the Law of Property in Early America, 2nd ed. Chapel Hill: University of North Carolina Press.

Turner, Elizabeth Hayes. 2008. Women and Gender in the New South. Hoboken: Wiley-Blackwell.

Teaver, Wyolene McGee. 1998-2002. Interviews by author. Telephone interview. LaGrange, GA, USA.

Tindall, George B. 1967. The Emergence of the New South, 1913-1945. Baton Rouge: Louisiana State University Press. Vogel, Marcel. 1959. Amasses a Different Kind of Wealth. In LaGrange (GA) Daily News, October 29, p. 1.

Whites, LeeAnn. 2000. The Civil War as a Crisis in Gender: Augusta, GA, 1860-1890. Athens: University of Georgia Press. White, Deborah Gray. 1999. Ar'n't I a Woman?: Female Slaves in the Plantation South. New York: W. W. Norton \& Co. Wheeler, Marjorie Spruill. 1993. New Women of the New South: The Leaders of the Woman Suffrage Movement in the Southern States. New York and Oxford: Oxford University Press.

Yockel, Michael. 2001. Lenora Slaughter Frapart, the Doyenne of the American Beauty Pageant. Straussmedia, January 31. Available online: http://www.nypress.com/lenora-slaughter-frapart-the-doyenne-of-theamerican-beauty-pageant/ (accessed 30 May 2017).

(C) 2017 by the author. Licensee MDPI, Basel, Switzerland. This article is an open access article distributed under the terms and conditions of the Creative Commons Attribution (CC BY) license (http://creativecommons.org/licenses/by/4.0/). 